\title{
Cecal dermoid masquerading dermoid cyst of ovary: a case report and review of the literature
}

\author{
Tushar Subhadarshan Mishra ${ }^{*}$ (D), Saubhagya Kumar Jena ${ }^{2}$, Supriya Kumari ${ }^{2}$, Suvendu Purkait ${ }^{3}$, \\ Pavithra Ayyanar ${ }^{3}$ and Pallabi Nayak ${ }^{2}$
}

\begin{abstract}
Background: The ovary is the most common site of occurrence of mature cystic teratomas (dermoid cysts). These are the most common ovarian germ cell tumor in the reproductive age group, accounting for 10-20\% of all ovarian neoplasms, with a 1-2\% risk of malignancy. A cecal dermoid cyst is a rare entity with only ten cases having been reported so far, eight of which could be retrieved as the rest were reported in different languages. None of these cases were managed laparoscopically. Here we present the first case of cecal dermoid managed laparoscopically.

Case presentation: A 35-year-old nulliparous Indian Hindu woman presented with complaints of on and off abdominal pain for 10 months. The abdominal examination revealed a well-defined mass of about $10 \times 5 \mathrm{~cm}$ size, palpable in the right iliac fossa. On sonography, it was suggestive of a right-sided ovarian dermoid cyst. The lesion measured $10 \times 7 \times 5 \mathrm{~cm}$ on a contrast-enhanced computed tomogram (CT) scan. It was well defined and hypodense and located in the right lower abdomen. The ovarian tumor markers were normal. On laparoscopy, the uterus, bilateral tubes, and ovaries were found to be healthy. The cyst was seen arising from the right medial wall of the cecum at the ileocecal junction, which was excised laparoscopically. Histopathological study revealed it to be a mature cystic teratoma.

Conclusion: Ovarian mature cystic teratoma commonly has an indolent course and can present with palpable abdominal mass, pain, or vomiting due to complications like torsion, hemorrhage, or infection. Alternatively, these cysts can be asymptomatic and incidentally detected. Clinicians should be aware of the variety of presentations of dermoid cysts of the bowel as well as mesentery. The exact location of the teratoma eluded us till the laparoscopy despite adequate imaging including a contrast-enhanced CT scan having been performed preoperatively. We are reporting this as it is a rare entity, and this knowledge will help gynecologists and surgeons make an appropriate surgical decision.
\end{abstract}

Keywords: Case report, Cecal neoplasm, Cecum, Dermoid cyst, Mature cystic teratoma

\section{Background}

Mature cystic teratomas (dermoid cysts) are the most

*Correspondence: tusharmishra@aiimsbhubaneswar.edu.in; doctushar@gmail.com

1 Department of General Surgery, All India Institute of Medical Sciences, Room No 403, Academic Building, AllMS Road, Patrapada, Sijua, Bhubaneswar, Odisha 751019, India

Full list of author information is available at the end of the article common ovarian germ cell tumor in women of reproductive age, constituting $10-20 \%$ of all ovarian neoplasms [1, 2]. They have a $1-2 \%$ risk of malignancy [1]. Predominantly they have a midline location, like the mediastinum, nasal sinuses, and pineal gland. Rarely they may occur at locations away from the midline, like the omentum, abdominal wall, retroperitoneum, and cecum. Various theories have been postulated regarding the development original author(s) and the source, provide a link to the Creative Commons licence, and indicate if changes were made. The images or other third party material in this article are included in the article's Creative Commons licence, unless indicated otherwise in a credit line to the material. If material is not included in the article's Creative Commons licence and your intended use is not permitted by statutory regulation or exceeds the permitted use, you will need to obtain permission directly from the copyright holder. To view a copy of this licence, visit http://creativecommons.org/licenses/by/4.0/. The Creative Commons Public Domain Dedication waiver (http://creativeco mmons.org/publicdomain/zero/1.0/) applies to the data made available in this article, unless otherwise stated in a credit line to the data. 
of dermoid off the midline. This case of a cecal dermoid closely mimicked an ovarian dermoid, and the actual location of the lesion was missed till surgery, despite contrast-enhanced computed tomography (CECT). This case is being reported because of its rarity and its potential to elude accurate diagnosis despite adequate investigations.

\section{Case presentation}

A 35-year-old nulliparous Indian Hindu woman presented to the obstetrics and gynecology out-patient department of our institute with intermittent complaints of pain in the right lower abdomen for 10 months. She attained menarche at 13 years of age, and her previous menstrual cycles were regular. She was married for 1 year and was trying to conceive. She had no known medical comorbidities.

On examination, she was of average built. A mass of $10 \times 5 \mathrm{~cm}$ was palpable in the right iliac fossa, which was non-tender, firm, and mobile. The lower pole was palpable. Per speculum examination was unremarkable. Per vaginal examination revealed the uterus to be anteverted, normal-sized, firm, mobile with the left fornix free, and a mass around $10 \times 5 \mathrm{~cm}$ size felt in the right fornix. The mass was non-tender, firm, and was separate from the uterus.

The hematological and biochemical parameters, including blood glucose and thyroid levels, were within normal limits. The urine examination was also normal. Ultrasonography revealed a $10 \times 5 \mathrm{~cm}$ sized, well-defined solid cystic lesion with calcification in the right iliac fossa

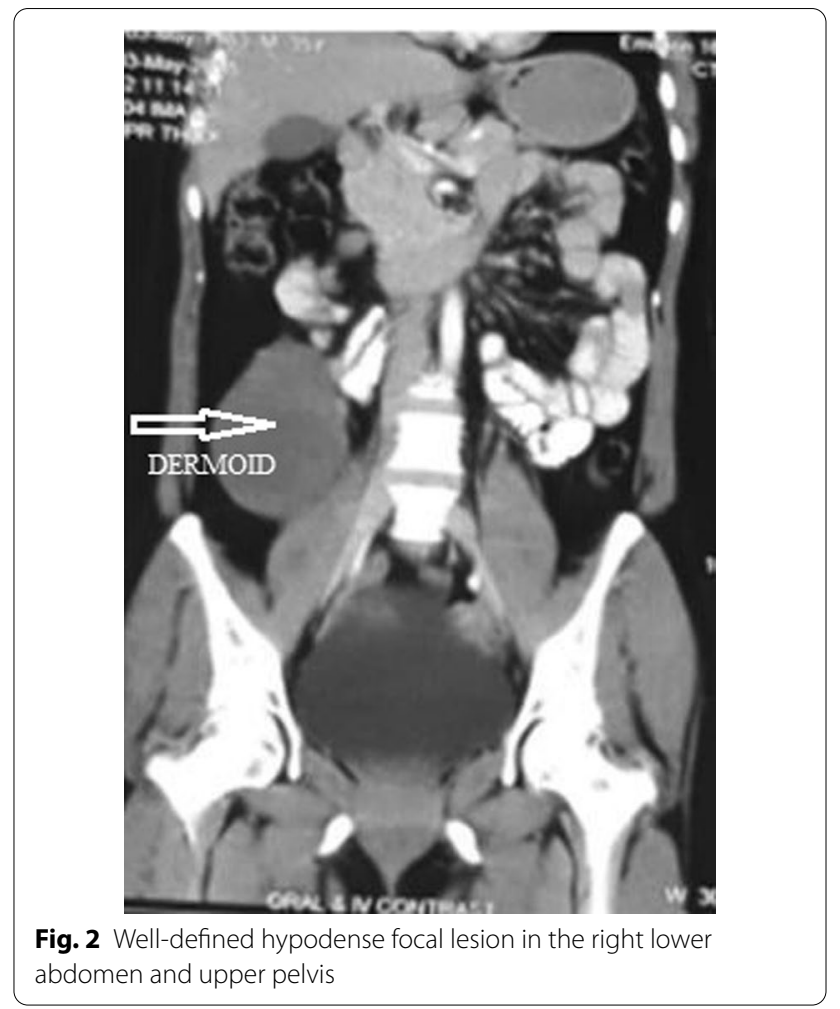

suggestive of right ovarian dermoid cyst. On Doppler, there was no abnormal flow (Fig. 1).

CECT showed a well-defined hypodense lesion of size $10 \times 7 \times 5 \mathrm{~cm}$ in the right lower abdomen (Fig. 2). The

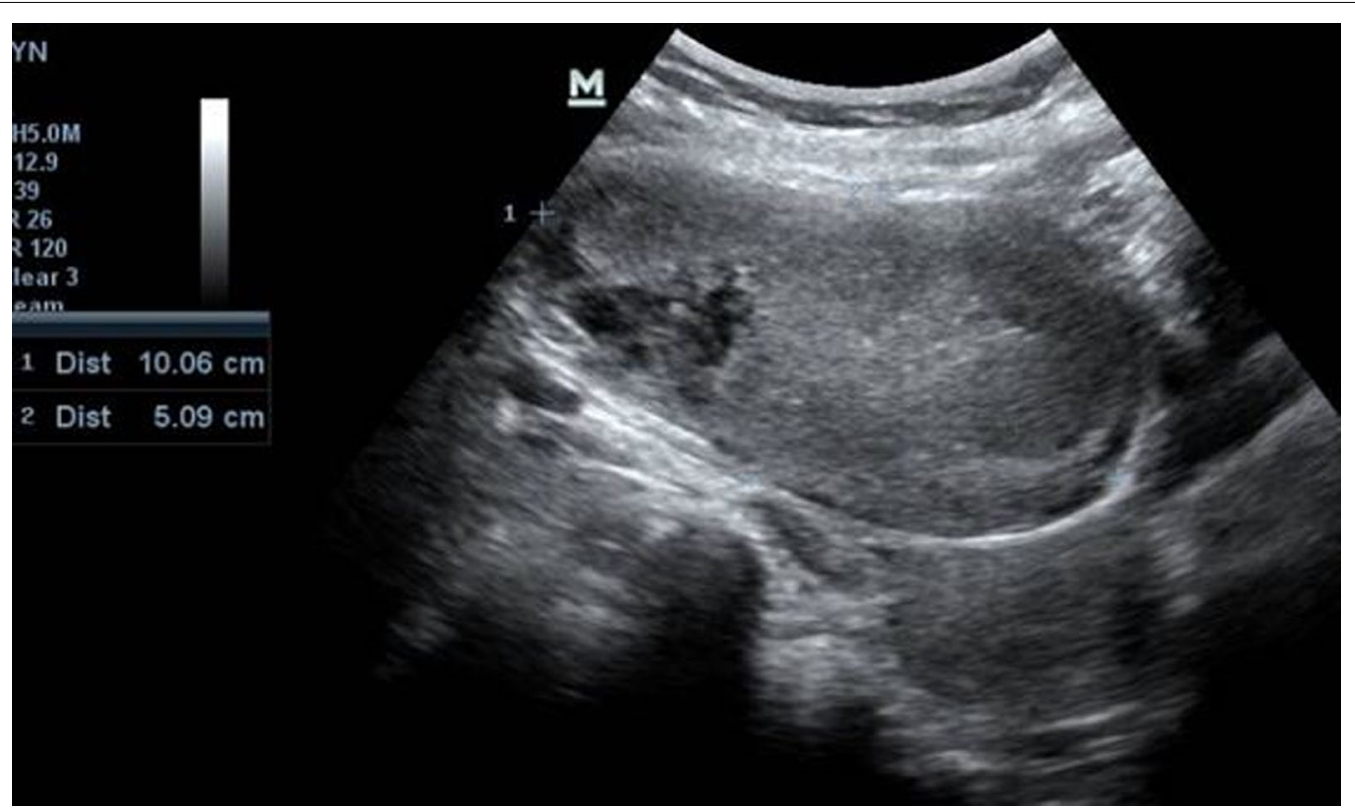

Fig. 1 Ultrasonography image showing a well-defined cystic and solid lesion with areas of calcification 
tumor markers CA-125 (8.8 U/ml), carcinoembryonic antigen $(1.58 \mathrm{ng} / \mathrm{ml})$, alfa fetoprotein $(3.25 \mathrm{ng} / \mathrm{ml})$, lactate dehydrogenase $(283 \mathrm{U} / \mathrm{l})$, and inhibin B $(29.11 \mathrm{pg} /$ $\mathrm{ml}$ ) were all normal.

On laparoscopy, the uterus, bilateral tubes, and ovaries appeared normal. A cyst of size $10 \times 6 \mathrm{~cm}$ was seen arising from the right medial wall of the cecum, at the ileocecal junction. The help of a surgeon was sought intraoperatively, and laparoscopic excision of the cecal dermoid was performed (Figs. 3, 4). The patient had an uneventful postoperative recovery.

Histopathological study revealed the cyst to be a mature cystic teratoma (Fig. 5). The patient is doing well and has attended regular follow-up for nearly two years now.

\section{Discussion and conclusion}

The word "teratoma," initially coined by Virchow in 1863, originates from the Greek word teraton, meaning monster. The term "dermoid cyst" used much earlier for the same entity was coined by Leblanc, and both descriptors are often used interchangeably [1].

Dermoid cysts can be classified as congenital or acquired. Acquired dermoid cysts may result from previous intra-abdominal surgery or trauma as a result of the seeding of the cutaneous tissue into the peritoneal cavity. Congenital dermoid cysts, however, have been postulated to occur as a result of implantation of the ectoderm during embryogenesis, when the neural groove closes [3].

Mature cystic teratomas commonly originate from the totipotent cells of the mature gonad. Rarely, germ cells which migrate in embryonic life can implant anywhere along the midline or paraxial regions of the body to give rise to extragonadal teratoma. While the omentum is the most common site, the cecum is a rare site for extragonadal teratoma [4].

The exact causes of extragonadal teratoma are yet to be ascertained. Thornton proposed the theory of

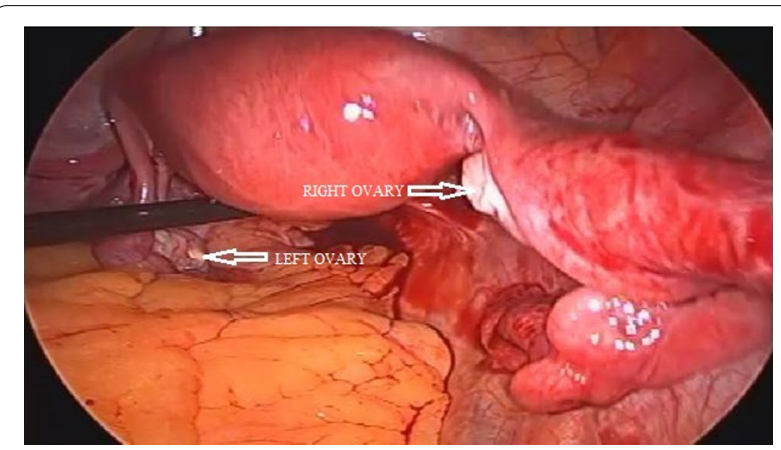

Fig. 3 Intraoperative image showing bilateral healthy ovaries

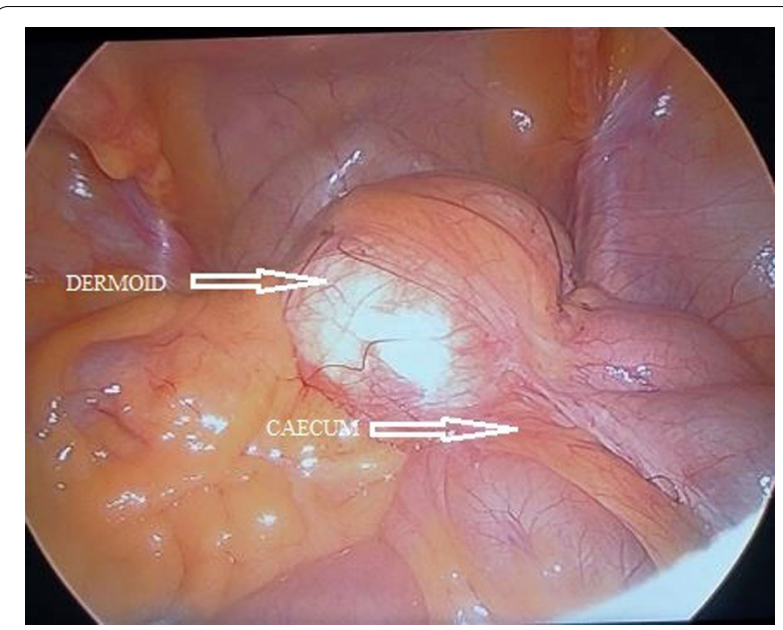

Fig. 4 Intraoperative images showing the cyst arising from the cecum

autoamputation of teratomas from an ovarian site reimplanting to another site in the abdomin [5]. This theory is widely accepted for the origin of extragonadal teratomas in the abdominal cavity. Rarely, the tumor may become entirely detached from the pedicle and become a parasitic teratoma. The mechanisms of autoamputation are still unclear. However, adnexal torsion is believed to lead to infarction, necrosis, and autoamputation. According to another theory, the extragonadal teratomas may occur in

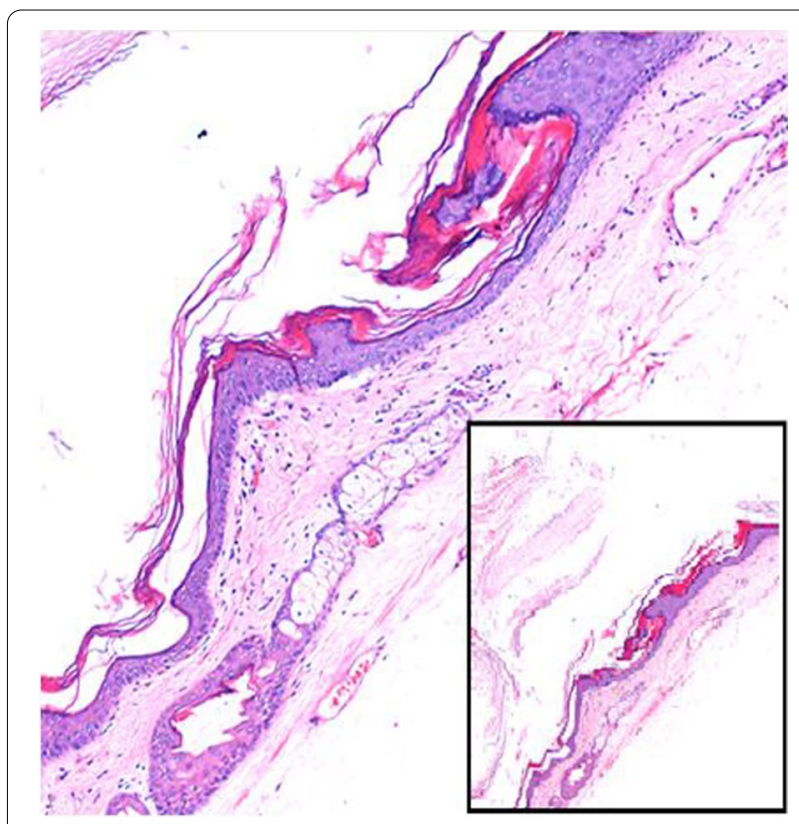

Fig. 5 Histopathology showing the squamous epithelium with the presence of a pilosebaceous unit in the subepithelium (hematoxylin and eosin, $\times 100)$. The inset showing keratin flakes with stratified squamous epithelium ( $\times 4$ magnification) 
Table 1 List of all the cecal dermoids reported to date

\begin{tabular}{|c|c|c|c|c|c|c|c|c|}
\hline Case no. & Age (years) & Sex & Author/reference & Symptom & Tumor size & $\begin{array}{l}\text { History of previous } \\
\text { surgery }\end{array}$ & Procedure & Year reported \\
\hline 1 & 1 & $\mathrm{~F}$ & Kay [7] & Abdominal mass & $8 \mathrm{~cm}$ & No & $\begin{array}{l}\text { Terminal ileum and } \\
\text { cecum resected }\end{array}$ & 1971 \\
\hline 2 & 53 & $\mathrm{~F}$ & Mossey [8] & Melena & $4 \mathrm{~cm}$ & $\begin{array}{l}\text { Hysterectomy appen- } \\
\text { dectomy }\end{array}$ & $\begin{array}{l}\text { Laparotomy_right } \\
\text { hemicolectomy }\end{array}$ & 1977 \\
\hline 3 & 34 & $\mathrm{~F}$ & Wilkinson [9] & $\begin{array}{l}\text { Colicky lower abdo- } \\
\text { men pain }\end{array}$ & $10 \mathrm{~cm}$ & 3 cesarean sections & $\begin{array}{l}\text { Laparotomy-right } \\
\text { hemicolectomy }\end{array}$ & 1996 \\
\hline 4 & 39 & $\mathrm{~F}$ & Mellado [10] & $\begin{array}{l}\text { Abdominal disten- } \\
\text { sion and pain }\end{array}$ & $20 \mathrm{~cm}$ & No & $\begin{array}{l}\text { Laparotomy_right } \\
\text { hemicolectomy }\end{array}$ & 2000 \\
\hline 5 & 34 & $M$ & Nirenberg [11] & Pain lower abdomen & $7.5 \mathrm{~cm}$ & No & $\begin{array}{l}\text { Laparotomy-cys- } \\
\text { tectomy with } \\
\text { appendectomy }\end{array}$ & 2001 \\
\hline 6 & 30 & $M$ & Schuetz [6] & $\begin{array}{l}\text { Pain right lower } \\
\text { abdomen }\end{array}$ & $8 \mathrm{~cm}$ & No & $\begin{array}{l}\text { Laparotomy_right } \\
\text { hemicolectomy }\end{array}$ & 2002 \\
\hline 7 & 41 & $F$ & Nahidi [12] & Heaviness and mass & $10 \mathrm{~cm}$ & No & $\begin{array}{l}\text { Laparotomy_right } \\
\text { Mikulicz colostomy }\end{array}$ & 2016 \\
\hline 8 & 2 & $M$ & Destro [13] & $\begin{array}{l}\text { Abdominal disten- } \\
\text { sion }\end{array}$ & $6 \mathrm{~cm}$ & $\begin{array}{l}\text { Anorectal malforma- } \\
\text { tion surgery }\end{array}$ & $\begin{array}{l}\text { Laparotomy-left } \\
\text { hemicolectomy }\end{array}$ & 2019 \\
\hline 9 & 35 & $\mathrm{~F}$ & Our case & $\begin{array}{l}\text { Pain right lower } \\
\text { abdomen }\end{array}$ & $10 \mathrm{~cm}$ & No & $\begin{array}{l}\text { Laparoscopic cystec- } \\
\text { tomy }\end{array}$ & 2020 \\
\hline
\end{tabular}

yrs $=$ years, $\mathrm{M}=$ Male, $\mathrm{F}=$ Female, $\mathrm{cm}=$ centimetres

an ectopic ovary, which may arise congenitally or following surgery or pelvic inflammation. A third theory suggests that they may originate from displaced primordial germ cells, which later may stop differentiating [5]. However, some authors have criticized these theories as the location of the cecum is off the midline when the neural groove or other epithelial fusion occurs. Cecum, however, is one of the last elements to re-enter the abdomen during the process of intrauterine rotation, at which time it could be taking up some of the congenital heterotopic tissue, which can give rise to the dermoid in the cecum [3].

Cecal dermoid cysts are rare entities, unlike the dermoid cysts from the gonads and other midline structures like the mediastinum, anterior neck, and central nervous system [6]. Continued reports of these cases will help understand and support the theories behind their origin, presentation, and classification.

There have been only ten cecal dermoid cases reported to date. Full-text literature could be retrieved for eight, but the remaining reports were in different languages. The details of these cases are listed in Table 1. Our case seems to be the first reported case of laparoscopic cecal dermoid cystectomy to the best of our knowledge. Although adequate radiological workup, including ultrasonography and computed tomography, was done in our case, the correct site of origin of the dermoid cyst remained elusive until the laparoscopy. The diagnostic dilemma was similar in all the previously reported cecal dermoids, where ascertaining the exact organ of origin was a problem. Excision by laparotomy and laparoscopy seems to be an effective form of curative treatment.

This case emphasizes the need for an accurate preoperative diagnosis to avoid intraoperative surprises, as happened to the gynecologists. Cecal dermoid should be kept in mind as a possibility wherever a diagnostic dilemma exists. Laparoscopy is not only feasible in the management of this condition but also carries a promise of lesser morbidity and early recovery.

\section{Acknowledgements}

The authors grant BioMed Central a license to publish the article and identify itself as the original publisher.

\section{Authors' contributions}

TSM, SKJ, SK, SP, PA and PN were involved in the patient's care. All authors have contributed substantially to collecting data, revising the article, and having given necessary intellectual inputs. SP and PA did the histopathological evaluation of this case. All authors read and approved the final manuscript.

Funding

The case report is non funded.

Availability of data and materials

Not applicable.

Ethics approval and consent to participate

Not applicable.

\section{Consent for publication}

Written informed consent was obtained from the patient for publication of this case report and any accompanying images. A copy of the written consent is available for review by the Editor-in-Chief of this journal. 


\section{Competing interests}

The authors have no conflicts of interest relevant to this article.

\section{Author details}

${ }^{1}$ Department of General Surgery, All India Institute of Medical Sciences, Room No 403, Academic Building, AllMS Road, Patrapada, Sijua, Bhubaneswar, Odisha 751019, India. ${ }^{2}$ Department of Obstetrics and Gynaecology, All India Institute of Medical Sciences, Bhubaneswar, Odisha, India. ${ }^{3}$ Department of Pathology, All India Institute of Medical Sciences, Bhubaneswar, Odisha, India.

Received: 30 August 2020 Accepted: 29 October 2020

Published online: 30 January 2021

\section{References}

1. Comerci JT, Licciardi F, Bergh PA, Gregori C, Breen JL. Mature cystic teratoma: a clinicopathologic evaluation of 517 cases and review of literature. Obs Gynecol. 1994;84(1):22-8.

2. Khanna S, Srivastava V, Saroj S, Mishra SP, Gupta SK. An unusual presentation of ovarian teratoma: a case report. Case Rep Emerg Med. 2012;2012:1-2.

3. Lao W, Stark R, Lendvay TS, Drugas GT. Cecal dermoid cyst. J Pediatr Surg Case Rep. 2014;2(7):347-9. https://doi.org/10.1016/j.epsc.2014.06.015.

4. Hegde P. Extragonadal omental teratoma: a case report. J Obstet Gynaecol Res. 2014:40(2):618-21.
5. Lee KH, Song MJ, Jung IC, Lee YS, Park EK. Autoamputation of an ovarian mature cystic teratoma: a case report and a review of the literature. World J Surg Oncol. 2016;14(1):1-7. https://doi.org/10.1186/s12957-016-0981-7.

6. Schuetz MJ, Elsheikh TM. Dermoid cyst (mature cystic teratoma) of the cecum: histologic and cytologic features with review of the literature. Arch Pathol Lab Med. 2002;126(1):97-9.

7. Kay S. Teratoid cyst of the cecum. Am J Dig Dis. 1971:16(3):265-8.

8. Mossey JF, Rivers L, Patterson P. Dermoid cyst of the cecum. Can Med Assoc J. 1977;117(12):1372.

9. Wilkinson N, Cairns A, Benbow EW, Donnai P, Buckley CH. Dermoid cyst of the cecum. Histopathology. 1996;29(29):186-8.

10. Mellado J, Bosch-Príncep R, Pérez-del-Palomar L. Ultrasonography and CT findings of a dermoid cyst of the cecum: a case report. Acta Radiol. 2000:41(5):489-91.

11. Nirenberg A, Buxton NJC, Kubacz GJ. Dermoid cyst of the cecum: case report. Pathology. 2001;33(2):246-7.

12. Nahidi A, Jazayeri S, Fathizadeh P. Dermoid cyst of the cecum: case report. Jundishapur J Oncol. 2016:2(1):15-9.

13. Destro F, Maestri L, Meroni M, et al. Colonic mature cystic teratoma. J Pediatr Surg Case Rep. 2019:41:57-9.

\section{Publisher's Note}

Springer Nature remains neutral with regard to jurisdictional claims in published maps and institutional affiliations.
Ready to submit your research? Choose BMC and benefit from

- fast, convenient online submission

- thorough peer review by experienced researchers in your field

- rapid publication on acceptance

- support for research data, including large and complex data types

- gold Open Access which fosters wider collaboration and increased citations

- maximum visibility for your research: over $100 \mathrm{M}$ website views per year

At BMC, research is always in progress.

Learn more biomedcentral.com/submissions 